\title{
Utilization of Solar Power Plant as an Alternative Energy Sources Solar Applications in Building System
}

\author{
${ }^{1}$ J. Jamaaluddin \\ ${ }^{I}$ Departement Electrical Engineering, University of Muhammadiyah Sidoarjo, Sidoarjo, Indonesia, \\ jamaaluddin@umsida.ac.id
}

\begin{abstract}
Solar energy is one source of energy and has advantages compared with fossil energy sources. Solar energy is very necessary to be researched and developed further, including at the University of Muhammadiyah Sidoarjo. Utilization of solar energy, it is by preparing the installation of Photovoltaic Cell (solar cells) to determine the placement position and angle of the slope. The utilization of solar power will be applied at the Laboratory of Electrical Engineering University of Muhammadiyah Sidoarjo to make Solar Building System (SBS). This study will carry out an analysis of the utilization of solar energy compared to using the resources of PT. State Electricity Company (PT. PLN). The analysis was done with the installation of SBS consider investment and installation costs grid drawn on the Net Present Value, and compare the operating cost between SBS with the grid system. This research show the results of the analysis in gain by using SBS will have a value higher efficiency compared to the grid system at a certain time span by considering Break Event Point (BEP) SBS installation investment. Over 21 Years.
\end{abstract}

Keywords: Solar energy, Solar Building System (SBS) SBS efficiency, Photovoltaic Cell (PV).

Paper type Research paper

\section{INTORDUCTION}

In this modern era, human needs on electrical energy are one of the basic needs and requirements of electrical energy is one indicator of the progress of a country. Today people still use fossil to meet its energy needs. So the longer dwindling, average growth - average energy requirement is estimated at 4.7\% per year during the years 2011 to 2030 [1], [2].

Solar Power Plant (SPP) is one of the developments of renewable energy use has the potential to be applied in Indonesia, which has the potential of solar radiation the average - average $4,8 \mathrm{kWh} / \mathrm{m} 2 /$ day [1] .work method of the photovoltaic cell (PV) depends on the sunlight it receives. Climatic conditions (e.g. cloud and fog) also had a significant effect on the amount of solar energy received by the cell so that it will affect their performance as well as proven [3], [4], $[5],[6],[7]$.

\section{METHOD}

An analysis conducted is the first investment costs required to connect electricity from PT. PLN, where the value of the investment will be used as the current value (Net Present Value) plus operating costs, emerged per month compared with the cost of investing SBS operational costs, research methods The Flow chart of research on this method is as shown in Figure 1 .

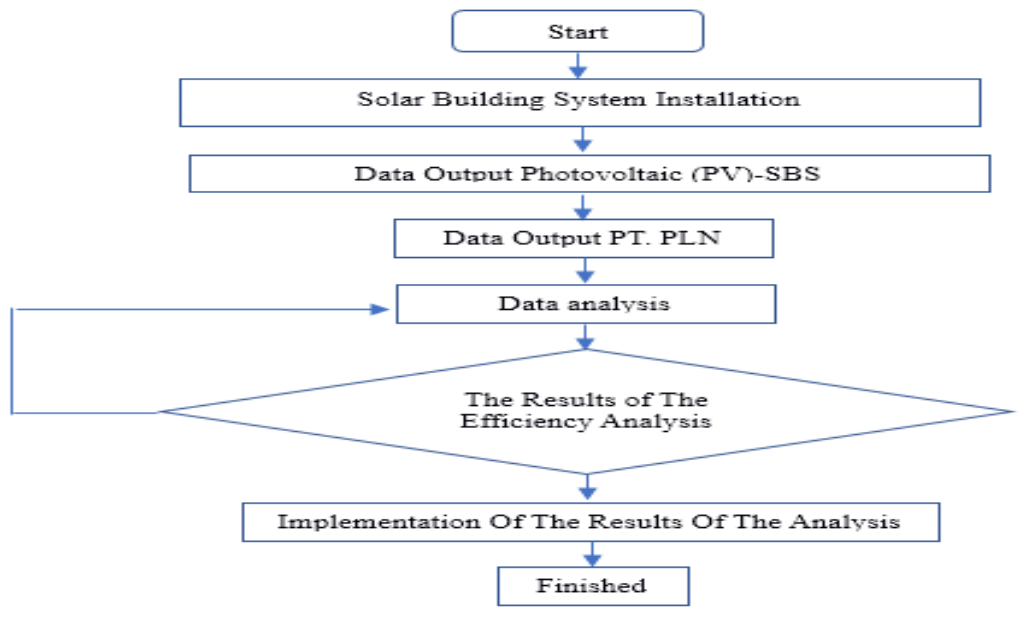

Fig. 1. Fig. 1. Flowchart of Research 
This study was conducted to plan the following activities, among others:

1. PV instalation on the campus of Electrical Engineering Laboratory of the University of Muhammadiyah 2 Sidoarjo. Along with the current storage device (accumulator), the charging control unit and the load. Simulated power consumption of PV is interconnected with the Sub Distribution Panel (SDP) in Electrical Engineering Laboratory.

2. Temperature collect and irradian the following PV PV voltage and current measurements at the time of load and no load.

3. Investment costs during the initial installation of PLN and monthly operating costs for laboratories Electrical Engineering. PLN initial installation investment data analysis to be present value (Net Present Value).

4. Investment costs at the time of the PV installation and operating costs appear to laboratory Electrical Engineering.

5. Comparative analysis of the efficiency of the power supply PLN with SBS both in terms of investment costs and operational costs.

6. Evaluation and repair

7. Report.

\section{RESUlTS AND DISCUSSION}

A. SSDP panel in Electrical Power Engineering Lab (TTL) and Energy Conversion (KE).

Electrical systems contained in the Laboratory of Electrical Engineering at Level 2 - Building Agriculture, sourced from SDP (Sub Distribution Panel) Main Gedng land located in Center Ground Floor, and distributed on each floor, including that in second floor with the designation Laboratory Electrical Engineering. Of SDP in the ground Floor entrance to the SSDP (Sub Sub Distribution Panel) located on the 2nd floor, and into each lab with the 3-phase concept. Given the need for practical use 3 phase system.

The panels are located at the Laboratory of Power Engineering and Energy Conversion (Lab TTL and KE), supply the needs of the power supply in the lab room, which consists of three kinds of loads, namely:

1. water Conditioning load.

2 Laboratory lighting load,

3. Laboratory Equipment load.

By depiction wiring diagram as shown in Figure 2.

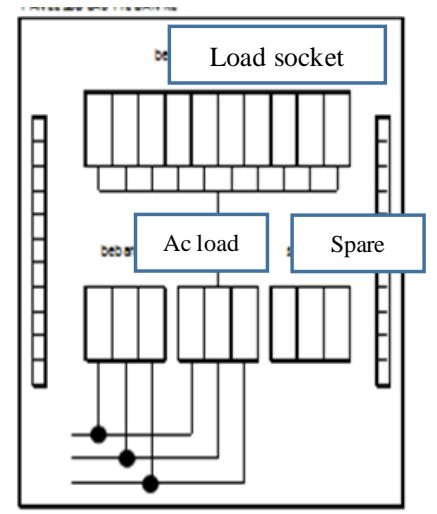

Fig. 2. Fig. 2. Wiring diagram Panel For Lab (TTL \& KE)

Total expenses are mounted on TTL \& KE Lab is as shown in the Table. 1:

TABLE I. TABLE 1 TABle LoAD Mounted on LAB (TTL \& KE)

\begin{tabular}{lllll}
\hline No & Load & Power & Amount & Total Power \\
\hline 1 & Air Conditioning & 900 Watt & 2 Unit & 1800 Watt \\
2 & TL Lamp & 30 Watt & 6 Unit & 180 Watt \\
3 & TV LED 32 Inch & 200 Watt & 1 Unit & 200 Watt \\
\hline
\end{tabular}

By using the formula below

Where :

$$
\mathrm{W}=\mathrm{V} \times \mathrm{I} \times \cos \varphi
$$

$\mathrm{P}=$ Power in (Volt Ampere)

$\mathrm{V}=$ Voltage in (Volt) 
$\mathrm{I}=$ current in (Ampere)

$\operatorname{Cos} \varphi=$ Power factor in this case is considered (0.8).

From equation (i) above, then get the formula (ii) below to determine the value of I.

$$
\mathrm{I}=\mathrm{W} /(\mathrm{V} \cdot \operatorname{Cos} \varphi)
$$

Then get the current calculation results on each load shown in Table 2.

TABLE II. TABLE 2 VALUES InSt Alled LoAd CURRENT (AMPERES)

\begin{tabular}{ccccc}
\hline No. & Load & Power & Amount & Total Current \\
\hline 1 & Air Conditioning & 900 Watt & 2 Unit & 10,23 Ampere \\
2 & TL Lamp & 30 Watt & 6 Unit & 1,02 Ampere \\
3 & TV LED 32 Inch & 200 Watt & 1 Unit & 1,14 Ampere \\
\hline \multicolumn{7}{c}{ Total } & & 12,39 Ampere \\
\hline
\end{tabular}

The current rating will later be used to compare how much money is needed to pay PLN on the existing load on Lab TTL \& KE, compared with the use of PV because of limited PV in the installation, the imposition of which was originally performed to all the existing load on Lab TTL and TO, then it changed to only a light load only.

\section{A. Panel Installation Network PVanel SSDP in Electrical Power Engineering Lab (TTL) and Energy Conversion} (KE).

PV network that goes into La TTL and KE do installation supply manual changing of the supplier of the PV system load and system load supplies PLN. The following illustrates a block diagram of the PV installation for the supply of laboratory space and KE TTL as Figure 3.

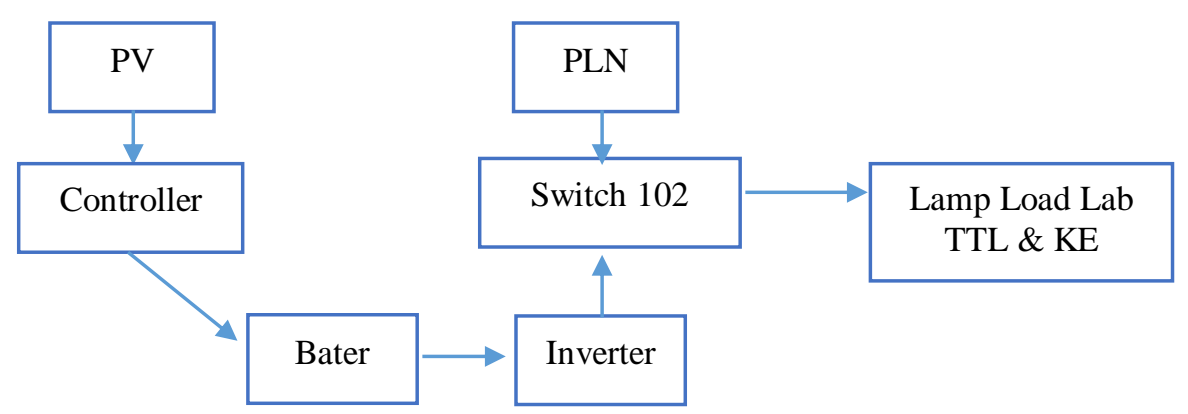

Fig. 3. Fig. 3. PV System Block Diagram and PLN in Lab TTL and KE

\section{B. Electricity Cost Calculation To Space Lab.}

Costs to be paid for the use of electric power in the Lab TTL \& KE can be calculated by mengasumsikaan that the lab is used for 8 hours per day, so assuming this will get the use of kilo watt hours per day, and if multiplied by a month then it will get the value kilo watt hours per month and multiplied by the electricity rate per kilo watt hour Rupiah her. Lab electrical charge so that TTL and KE will know how much per month.

The investment value of the electrical installation are also taken into account by using past values into present values and summed with the value of its use. This value will be compared to the value when used with PV value daily operations, and maintenance costs plus the present value of investment costs.

Lab electrical power consumption TTL \& KE for 1 month is (assuming the use of:

1. 07:30 am untill $14.00 \mathrm{pm}=6.5$ hours rounded up to 7 hours

2. $16: 00 \mathrm{pm}$ untill $21: 00 \mathrm{pm}=5$ hours with sorting

a. Time to peak load (PLT) at 17:00 to 21:00 = 4 hours.

b. out time peak load (OPLT) at 16:00 to $17: 00=1$ hour

So to use WBP $=4$ hours per day, and

OPLT 8 hours per day.

Assuming the use of the Lab for 25 days in a month, then get the results of the calculation as follows:

The use of PLT $=180 \mathrm{~W}$ x 4 hours / day x 25 days 


$$
=18,000 \mathrm{Wh}=18 \mathrm{kWh}
$$

Usage OPLT $=180 \mathrm{~W}$ x 8 hours $/$ day $\times 25$ days

$$
=36,000 \mathrm{Wh}=36 \mathrm{kWh}
$$

Assuming that electricity is used campus social groups with power above $200 \mathrm{kVA}$. For the determination of peak load and peak load time Outer done using analysis:

The use of PLT $=18 \mathrm{kWh} \times 1.4 \times$ Rp. $1,035 / \mathrm{kWh}$

$$
=\text { Rp. } 26082
$$

Usage OPLT $=36 \mathrm{kWh} \times \mathrm{Rp} .1,035 / \mathrm{kWh}$

$$
=\text { Rp. } 37260
$$

So that the amount of the costs incurred for electricity consumption Lab TTL \& KE amounted $=$ Rp. $63342 /$ month.

C. Installation costs beginning PLN System

The cost of the initial installation of the system that existed at the Lab PLN TTL \& KE is the lowest capacity PLN, ie Rp. 421,000, - (Empmat Hundred Twenty Thousand). Plus with SLO (Certificate of Operation Worthy) Rp. 40.000, -, plus the installation cost of approximately Rp. 500.000, - then less than the cost of a new pair of electricity to the capacity of 450 kVA, is Rp. 961 000, - (Nine Hundred Sixty Puuh One Thousand) are rounded to approximately Rp. 1.000.000, - (One Million).

D. Investment costs Procurement PV

In this study, procurement of PV, the following is a complete system with details and pricing shows in Table 3.

TABLE III. TABLE. 3. THE PRICE OF PV SYSTEM COMPONENTS

\begin{tabular}{ccccc}
\hline No. & Material & Quantity & Unit Price (RP) & Total Price (Rp) \\
\hline 1 & Photo Voltaic 100 & 3 & 1.750 .000 & 3.250 .000 \\
2 & PWM Controller 10-15 A & 1 & 600.000 & 600.000 \\
3 & MPPT Controller 10-15 A & 1 & 675.000 & 675.000 \\
4 & Inverter 200 W & 1 & 300.000 & 300.000 \\
5 & Material Support PV & 1 & 500.000 & 500.000 \\
6 & Cable & 1 & 250.000 & 250.000 \\
7 & Battery & 2 & 800.000 & 800.000 \\
8 & Nut and Bolt & 1 & 100.000 & 100.000 \\
9 & Labor & 1 & 2.500 .000 & 2.500 .000 \\
\hline
\end{tabular}

From Table 3. it can be concluded that the price of PV units are:

$$
\mathrm{PV}=\frac{\text { Rp. } 10.975 \text { million }}{290 \mathrm{WP}}=\mathrm{Rp} .37844 / \mathrm{WP}
$$

Such that this value can be used as a matter on a larger scale PV, then the unit price can be used as a benchmark.

\section{E. Cost Analysis of Electricity Terkuragiaya}

To supply the load Lighting of the Lab TTL and TO, with the capacity to supply the load lighting is equal to: 180 Watt, with output voltage 12 Volt battery, and should be changed by using an inverter to $220 \mathrm{~V}$, the full battery capacity of 80 $\mathrm{AH}$, will be able to supply lights for:

$$
\begin{aligned}
& \frac{180 \mathrm{~W}}{12 \mathrm{~V}}=15 \mathrm{~A} ; \\
& \text { then to the battery capacity }=80 \mathrm{AH}
\end{aligned}
$$

Then it will be supplying the lighting load for $=80 \mathrm{AH}=5$ hours. So the cost PLN to within 5 hours at night when it is equivalent to

= 180 watts x 5 hours x 1.4 x Rp. 1,035/kWh / 1000

$=$ Rp. 1,304

In one month there were savings

$=$ Rp. 1,304 x 30 Days

= Rp. 39 123, - 
F. Comparison of Operating Costs and Investments PV Compared With the reduced fee analysis PLN Electricity Costs reduced

Once all the data gathered, it is done comparing the cost of investment required at the time of initial purchase, maintenance costs and operating costs between SBS with PLN. The results can be seen in Table 4.

TABLE IV. TABLE 4. COMPARISON OF SBS AND PLN COSTS

\begin{tabular}{cccc}
\hline No & Description & SBS & PLN \\
\hline 1 & Initial Investment & 10.975 .000 & 1.000 .000 \\
2 & Operational Costs Every Month & 0 & 39.125 \\
3 & Maintenance Costs & 0 & 0 \\
\hline
\end{tabular}

Then the SBS investment costs will be equal to the operational costs PLN:

$=10975000-1000000=254.97$ months $=21$ years

The assumption that certainly will have results, if the capacity of the building to be installed is greater. It is because of the cost of costs that are not part moves linearly rising to follow their installed capacity. However, from the side of his electricity costs, PLN for greater capacity will increase logarithmically and tend to be sharp.

\section{CONCLUSION}

From the above explanation of the results of this study, it was concluded the following conclusions:

1. Use of SBS, it will require an initial investment of procurement and installation of the device.

2. PLN has the opposite characteristics, low cost of investment, but customers at a heavy emphasis on the monthly electric bill.

3. Adobtained price per $\mathrm{kWh}$ to the cost of procurement and installation of SBS. It is necessary for the calculation of the early development of SBS, with a value of Rp. 37844 / WP.

4. Had in a long time get the break-even point (BEP) procurement and installation costs of PV, which amounted to 23 Years.

Suggestion to improve for the next research are as follow:

1. Research needed further and deeper for larger PV capacity. So it will get a value per kW supply and installation of PV.

2. Required further study and in-depth PV capacity, so that we will get the value of the length of the break-even point (BEP) are more precise.

\section{ACKNOWLEDGMent}

Further thanks to the University of Muhammadiyah Sidoarjo, which has been assisting morale and Petition on internal research schemes Universitas Muhammadiyah Sidoarjo [1]-[3].

\section{REFERENCES}

[1] D. E. Nasional, “Outlook Energi Indonesia 2014,” Jakarta Dewan Energi Nas., 2014.

[2] I. Robandi, "Short term load forecasting of Eid Al Fitr holiday by using interval Type-2 Fuzzy Inference System (Case study: Electrical system of Java Bali in Indonesia)," in 2016 IEEE Region 10 Symposium (TENSYMP), 2016, pp. 237-242.

[3] M. D. J. Pucar and A. R. Despic, "The enhancement of energy gain of solar collectors and photovoltaic panels by the reflection of solar beams," Energy, vol. 27, no. 3, pp. 205-223, 2002.

[4] S. Younes, Claywell R., and T. Muneer, "Quality control of solar radiation records: Present status and proposed new approaches," in Energy, 2005, vol. 30, no. 9 SPEC. ISS., pp. 1533-1549.

[5] M. S. R.Y. S and F. S. M. Rif'an, and H. P. Sholeh, "Optimization of Power Solar Energy Utilization in UB's Department of Electrical Engineering," EECCIS Vol. 6, No. 1, June 2012.

[6] California Energy Commission, "A guide to photovoltaic system design and installation," Calif. Energy Comm., June, 2001 , pp. 39.

[7] M. Bortolini, M. Gamberi, and A. Graziani, "Technical and economic design of photovoltaic and battery energy storage system," Energy Convers. Manag., Vol. 86, 2014, pp. 81-92. 